\title{
Pengendalian Bahan Baku Tebu di Pabrik Gula Madukismo, Bantul, Yogyakarta
}

\section{Control of Sugar Cane Raw Materials at Madukismo Sugar Factory, Bantul, Yogkarta}

Dwinita Agustiana*, Pandi Pardian

Program Studi Agribisnis, FakultasPertanian, Padjadjaran University

\section{ARTICLE INFO}

Article history:

Diterima 03-Maret-2019

Diperbaiki 19-April-2019

Disetujui 25-April-2019

Kata Kunci:

Bahan baku, Economic

Production Quantity,

Kuantitas, Pengendalian, optimal, efisien

\begin{abstract}
ABSTRAK
Pabrik Gula (PG) Madukismo merupakan perusahaan agroindustri yang memproduksi gula untuk kebutuhan konsumsi gula pasir di Indonesia sehingga dituntut melakukan produksi berkelanjutan selama musim giling. Namun, PG Madukismo masih mengalami permasalahan, yaitu bahan baku yang tersedia belum memenuhi target karena mengalami fluktuasi. Oleh karena itu, PG Madukismo membutuhkan pengendalian bahan baku tebu untuk memperoleh kuantitas yang tepat agar produksi berjalan lancar dan berkelanjutan. Penelitian ini bertujuan untuk menganalisis kuantitas persediaan bahan baku yang optimal dalam setiap hari giling dan biaya total yang dikeluarkan PG Madukismo dalam melakukan produksi dengan metode Economic Production Quantity (EPQ). Penentuan lokasi dilakukan secara sengaja (purposive) dengan pertimbangan bahan baku yang tersedia belum memenuhi target, yaitu pabrik terkadang mengalami kelebihan dan kekurangan bahan baku. Hasil penelitian menunjukkan bahwa jumlah persediaan bahan baku yang optimal menggunakan metode $E P Q$ pada tahun 2018 adalah 41.529 kuintal. Total biaya produksi yang dikeluarkan dengan metode tersebut sebesar Rp 896.333.840 sehingga menurunkan biaya total persediaan sebesar $66,7 \%$.
\end{abstract}

\section{ABSTRACT}

Keywords: control, Economic Production Quantity, efficient, optimal, raw materials, quantity

\begin{abstract}
Sugar mill (PG) Madukismo is an agro-industry company that produces sugar for sugar consumption needs in Indonesia so it is required to carry out sustainable production during the milling season. However, PG Madukismo is still experiencing problems, namely the available raw materials have not met the target due to fluctuations. Therefore, PG Madukismo requires controlling sugar cane raw materials to obtain the right quantity so that production runs smoothly and sustainably. This researh aims to analyze the optimal quantity of raw material inventories in each milled day and the total costs incurred by PG Madukismo in making production using the Economic Production Quantity (EPQ) method. Location determination is done intentionally (purposive) considering that the available raw materials do not meet the target, namely the factory sometimes experiences the advantages and disadvantages of raw materials. The results showed that the optimal amount of raw material inventory using the EPQ method in 2018 was 41,529 quintals. The total production costs incurred by this method amounted to Rp 896.333 .840 thus reducing total inventory costs by $66,7 \%$.
\end{abstract}

\section{Pendahuluan}

Pabrik Gula Madukismo merupakan salah satu perusahaan agroindustri yang memproduksi gula guna memenuhi kebutuhan konsumsi gula pasir di Indonesia. Sehingga dituntut untuk melakukan produksi secara berkelanjutan selama musim giling. Dalam melakukan kegiatan produksinya PG Madukismo membutuhkan bahan baku. Menurut [1]. dalam setiap kepentingan perusahaan pengelolaan bahan baku sangatlah penting dalam keseluruhan kinerjanya. Perusahaan dalam memperoleh keuntungan dalam memproduksi barang memerlukan manajemen bahan baku yang baik karena bahan baku merupakan faktor penting dalam proses produksi [2]. Permasalahan yang sering dialami oleh sebuah perusahaan adalah persediaan bahan baku yang tidak 
sesuai dengan kebutuhan perusahaan terutama dari segi kuantitas yang mengakibatkan terganggunya proses produksi. Persediaan yang berlebihan akan mengakibatkan kerugian perusahaan yaitu adanya biaya-biaya yang ditimbulkan dengan adanya persediaan tersebut. Sebaliknya menurut [3], kekurangan persediaan dapat menimbulkan kerugian perusahaan karena akan menggangu perusahaan dalam kegiatan produksi dan distribusi.

Bahan baku utama yang dibutuhkan Pabrik Gula Madukismo dalam proses produksinya adalah tebu. Tebu merupakan tanaman semusim yang dapat ditebang saat rendemen pada posisi optimal yaitu umur sekitar 10 bulan [4]. Tebu merupakan bahan baku agroindustri yang memiliki sifat mudah rusak yaitu jika didiamkan terlalu lama kualitas tebu akan menurun. Berdasarkan penelitian [5], tebu yang sudah ditebang cepat mengalami penurunan kualitas dan mengalami penyusutan jika setelah 36 jam tidak segera dilakukan pemrosesan. Hal tersebut mempengaruhi penurunan produksi gula yang dihasilkan. Semakin lama penundaan, nira yang dihasilkan menurun karena kadar air dalam tebu mengalami penguapan, sedangkan kandungan zat padat pada nira akan meningkat dan menimbulkan terjadinya peningkatan viskositas nira. Semakin tinggi viskositas nira maka akan menyulitkan proses pemurnian. Hal tersebut berpengaruh terhadap penurunan produksi gula yang dihasilkan. Oleh karena itu, Pabrik Gula Madukismo perlu melakukan standar penundaan giling yaitu selama 36 jam dan tebu yang diproses sebagai bahan baku memiliki kandungan rendemen 6-8 \% serta masih dalam standar kualitas yang ditetapkan, yaitu tebu Bersih Segar dan Manis (BSM).

Pabrik Gula Madukismo dalam memenuhi kebutuhan bahan baku tebunya yaitu dengan melakukan kerja sama dengan petani. Ada 3 pola kerja sama yaitu Tebu Rakyat Mandiri, Tebu Rakyat Kemitraan, dan Tebu Rakyat Kerja Sama Usaha. Tebu Rakyat Mandiri merupakan kemitraan yang keseluruhan kinerjanya dilakukan oleh petani, mulai dari pencarian lahan, biaya, dan pengerjaan kebun. Tebu Rakyat Kemitraan merupakan pola kerja sama yang mana Pabrik Gula Madukismo bermitra dengan pemilik lahan dan Pabrik Gula Madukismo sepenuhnya mengelola perkebunan dengan Sinder Kebun Wilayah (SKW) sebaga penanggungjawab. Tebu Rakyat Kerja sama Usaha merupakan pola kerja sama dengan pengelolaan bersama antara Pabrik Gula Madukismo dan petani dengan menjadikan kelompok petani sebagai pengelola lahan dan Pabrik Gula Madukismo terlibat dalam aspek teknisnya.

Menurut Tabel 1 menunjukkan bahwa produksi tebu dalam satu periode giling masih kurang dari target produksi tebu yang ditetapkan oleh Pabrik Gula Madukismo. Hal tersebut karena bahan baku tebu yang dihasilkan di Pabrik Gula Madukismo tergantung luas lahan yang ditanami tebu yang pada dasarnya semakin berkurang. Luasan lahan yang ditanami tebu di wilayah kerja Pabrik Gula Madukismo ratarata lahan Tebu Rakyat Kemitraan (TRM). Selain dilihat dari persediaan tebu yang masih kurang atau belum mencapai target, pengelolaan bahan baku di Pabrik Gula Madukismo masih sering mengalami kendala yaitu ketidakseragaman jumlah tebu yang datang menjadikan sulitnya pengendalian jumah persediaan tebu yang akan digiling.
Tabel 1.

Pola Kerja sama, Luas Lahan Tebu, Target Bahan Baku, Rendemen, dan Hasil Produksi Gula Pabrik Gula Madukismo tahun 2013-2018

\begin{tabular}{|c|c|c|c|c|}
\hline Tahun & Uraian & $\begin{array}{l}\text { Luas } \\
\text { Lahan } \\
(\mathrm{Ha})\end{array}$ & $\begin{array}{c}\text { Target } \\
\text { Produksi } \\
\text { Tebu } \\
\text { (Kuintal) }\end{array}$ & $\begin{array}{c}\text { Realisasi } \\
\text { Produksi } \\
\text { Tebu } \\
\text { (Kuintal) }\end{array}$ \\
\hline \multirow[t]{4}{*}{2013} & KSU & 494,43 & 493,904 & 404.22 \\
\hline & KMT & $1.926,56$ & $1.250,88$ & 1081.439 \\
\hline & TRMan & 3.037 .45 & $1.467,115$ & 1415.828 \\
\hline & Jumlah & $5.458,44$ & $3.211,899$ & $2.901,487$ \\
\hline \multirow[t]{4}{*}{2014} & KSU & 434,46 & 577.818 & 302.217 \\
\hline & KMT & $1.885,85$ & 1.159 .988 & 899.035 \\
\hline & TRMan & $3.337,42$ & 1.539 .628 & 1.348 .596 \\
\hline & Jumlah & $5.657,73$ & 3.277 .434 & 2.549 .848 \\
\hline \multirow[t]{4}{*}{2015} & KSU & 435,54 & 354.710 & 325.731 \\
\hline & KMT & $1.831,54$ & 1.089 .565 & 838.496 \\
\hline & TRMan & $3.128,03$ & 1.366 .203 & 1.138 .260 \\
\hline & Jumlah & $5.395,11$ & 2.810 .478 & 2.302 .487 \\
\hline \multirow[t]{4}{*}{2016} & KSU & 397,44 & 332.831 & 353.479 \\
\hline & KMT & $1.767,79$ & 1.009 .216 & 1.027 .879 \\
\hline & TRMan & $2.846,93$ & 1.111 .247 & 1.231 .982 \\
\hline & Jumlah & $5.012,16$ & 2.453 .294 & 2.613 .340 \\
\hline \multirow[t]{4}{*}{2017} & KSU & 350,08 & 288.630 & 204.734 \\
\hline & KMT & $1.731,2$ & 1.034 .736 & 749.991 \\
\hline & TRMan & $2.694,85$ & 1.177 .224 & 896.058 \\
\hline & Jumlah & $4.776,13$ & 2.500 .590 & 1.850 .783 \\
\hline \multirow[t]{4}{*}{2018} & KSU & 314,64 & 284.897 & 232.940 \\
\hline & KMT & $1.942,92$ & 1.186 .405 & 919.859 \\
\hline & TRMan & $2.643,36$ & 996.921 & 733.315 \\
\hline & Jumlah & $4.900,92$ & 2.468 .223 & 1.886 .114 \\
\hline
\end{tabular}

Hal ini dapat dapat merugikan perusahaan karena pabrik terkadang mengalami kekurangan persediaan ataupun sebaliknya. Kondisi ini terjadi karena waktu kedatangan dan jumlah tebu yang masuk belum terjadwal dengan baik sehingga menyebabkan tingkat persediaan bahan baku tidak sesuai dengan target giling yang diharapkan sebesar 35.000 kuintal/hari. Realisasi giling tebu per hari dalam satu periode giling berbeda-beda tergantung dengan tebu yang masuk dan tingginya sisa pagi. Sisa pagi merupakan tebu yang digunakan untuk berjaga-jaga apabila terjadi keterlambatan pada kedatangan tebu di hari berikutnya. Kondisi ini disebabkan karena Pabrik Gula Madukismo harus menampung seluruh tebu yang datang dengan jumlah yang beragam walaupun dengan kondisi pabrik yang sudah tidak menginginkan bahan baku karena terjadi penumpukkan. Hal tersebut menyebabkan terjadinya penurunan kualitas tebu yang ditetapkan Pabrik Gula Madukismo yaitu Bersih Segar dan Manis (BSM).

Pada kondisi tersebut Pabrik Gula Madukismo tidak dapat menggiling tebu dalam jumlah yang optimal walaupun banyak tebu yang masuk dan banyaknya sisa pagi. Hal ini dikarenakan Pabrik Gula Maduksimo dalam melakukan produksinya dengan cara konvensional yaitu dengan 
mempertimbangkan kapasitas giling pabrik dan keberlanjutan hari giling berikutnya. Sehingga sisa pagi yang ada di Pabrik Gula Madukismo tersebut sangat tinggi yang dapat menurunkan kualitas tebu. Dengan adanya fenomena tersebut Pabrik Gula Madukismo membutuhkan pengaturan dan pengendalian bahan baku tebu yang tepat, salah satunya dengan penerapan metode Economic Production Quantity $(E P Q)$. Metode ini digunakan untuk menentukan jumlah bahan baku yang optimal sehingga proses produksi berkelanjutan dan berjalan lancar. Dengan ini diharapkan PG Madukismo dapat mengurangi resiko kerugian dalam persediaan bahan baku tebu baik dari segi kualitas tebu maupun dari segi biaya.

\section{Metode Penelitian}

Metode penelitian yang digunakan yaitu kualitatif. Menurut [6], penelitian kualitatif merupakan penelitian yang bertujuan untuk mendeskripsikan atau menggambarkan fenomena-fenomena yang ada, baik yang bersifat alamiah maupun rekayasa manusia, yang lebih memperhatikan mengenai karakteristik, keterkaitan antar kegiatan, dan kualitas.

Teknik pelaksanaan penelitian ini yaitu studi kasus [7], menyatakan bahwa studi kasus merupakan proses meneliti secara cermat terhadap peristiwa, aktivitas, proses, aktivitas individu maupun sekelompok. Studi kasus dalam penelitian bertujuan untuk memberikan uraian mendalam terhadap suatu hal. Penelitian ini menggunakan teknik penelitian studi kasus untuk mengetahui pengendalian bahan baku yang optimal menggunakan metode EPQ pada Pabrik Gula Madukismo Yogyakarta.

Objek dalam penelitian ini adalah pengendalian bahan baku tebu menggunakan metode Economic Production Quantity (EPQ). Informan yang diteliti yaitu menggunakan sampel Non Probability artinya setiap anggota populasi tidak memiliki kesempatan atau peluang yang sama sebagai sampel. Peneliti melakukan wawancara terhadap informan atau responden menggunakan teknik penentuan sampel berupa purposive sampling yaitu merupakan teknik penentuan sampel dengan pertimbangan khusus sehingga layak dijadikan sampel. Untuk mencari informasi yang akan dikaji responden langsung pada pihak yang berwenang di perusahaan. Kegiatan penelitian dilakukan dengan mengajukan wawancara ke bagian tanaman, instalasi, pabrikasi, Sumber Daya Manusia, dan Akutansi. Bagian tersebut meliputi kepala bagian tanaman, kepala rayon, kepala tebang dan angkut, sinder kebun wilayah, kepala tebu luar daerah, kepala Bina Sarana Tani, kepala instalasi, kepala derek, kepala remise, bagian SDM, dan bagian keuangan atau akutansi.

\subsection{Jenis dan sumber data yang digunakan}

\subsubsection{Data Primer}

Data yang diperoleh secara langsung atau data yang dikumpulkan melalui pihak pertama, biasanya dapat melalui jejak pendapat, wawancara dan lain-lain [8]. Sumber data ini berdasarkan hasil wawancara dengan pihak yang berwenang pada perusahaan yaitu bagian tanaman, tebang angkut, akutansi, Bina Sarana Tani, Sumber Daya Manusia, instalasi, pabrikasi, tebu luar daerah,

\subsubsection{Data Sekunder}

Data yang telah terlebih dahulu dikumpulkan dan dilaporkan oleh orang diluar penyelidik sendiri atau data yang diperoleh dari pihak kedua, biasanya diperoleh melalui instansi yang bergerak dalam pengumpulan data [9]. Sumber data berupa data yang diperoleh dari dokumen perusahaan.

\subsection{Metode pengumpulan data}

\subsubsection{Membaca Data dan Laporan}

Kegiatan ini peneliti mempelajari data-data yang ada di perusahaan dengan tujuan untuk mengetahui hal-hal apa saja yang sudah terjadi di perusahaan. Selain itu juga agar bisa dijadikan gambaran dan bahan dalam pembuatan penelitian. Pada kesempatan ini peneliti membaca dan mempelajari datadata tentang laporan keuangan meliputi data biaya persiapan giling, biaya penyimpanan bahan baku, biaya kekurangan bahan baku, dan biaya total perusahaan dalam melakukan produksi, data dan laporan pola kemitraan yang meliputi daftar perkebunan tebu, lahan perkebunan tebu, produksi tebu, dan rendemen, data tebang angkut yang meliputi kuantitas tebang angkut dan kuantitas giling.

\subsubsection{Wawancara}

Kegiatan ini peneliti melakukan wawancara untuk mencari informasi yang akan dikaji langsung pada pihak yang berwenang di perusahaan. Dalam kegiatan wawancara ini halhal yang didapatkan oleh peneliti adalah yang berkaitan langsung dengan kejadian di lapangan pada saat proses produksi berlangsung dan melakukan tanya jawab di bagian rayon dan tebang angkut yang meliputi bagaimana pengadaan bahan baku yang ada di PG Madukismo saat ini, proses pengadaan bahan baku, dan kendala dalam melakukan pengadaan bahan baku, bagian rayon yang meliputi pola kemitraan yang dilakukan oleh PG Madukismo, dan keuangan atau akutansi meliputi biaya-biaya dalam pengadaan bahan bahan baku, biaya penyimpanan bahan baku, dan biaya total dalam melakukan produksi.

\subsubsection{Observasi}

Kegiatan ini peneliti langsung melihat ke lapangan untuk mengetahui hal-hal apa saja yang terjadi saat proses produksi dan operasi berlangsung, serta melihat jenis bahan baku di gudang. Selain itu juga observasi ini bertujuan untuk menyesuaikan antara teori yang telah didapatkan oleh peneliti sebelumnya dan praktik di lapangan. Pada kegiatan ini peneliti didampingi oleh pembimbing lapangan yang telah ditunjuk oleh perusahaan.

\subsubsection{Studi Pustaka}

Pengumpulan data yang dilakukan dengan membaca jurnal, internet, buku-buku literatur, majalah, dan penelitian terdahulu yang berkaitan dengan penelitian yang sedang dilakukan.

\subsection{Metode analisis data}

Metode analisis data yang digunakan yaitu metode Economic Production Quantity (EPQ). Economic Production Quantity (EPQ) merupakan pengembangan model persediaan yang mana pengadaan bahan baku pada komponen tertentu 
diproduksi secara masal dan digunakan sendiri oleh perusahaan [9]. Economic Production Quantity (EPQ) atau tingkat produksi optimal adalah sejumlah produksi tertentu yang dihasilkan dengan cara meminimumkan total biaya persediaan yang terdiri atas biaya penyimpanan dan biaya setup produksi. Model EPQ merupakan model persediaan dengan penerimaan bertahap, karena jika bahan baku diproduksi sendiri, umumnya produk yang diproduksi akan ditambahkan secara berangsur-angsur karena mesin yang dimiliki terbatas dan berproses secara berangsur bukan serentak. Maka suatu pabrik akan berputar secara terus menerus dan pada saat yang sama harus memenuhi permintaan hingga terdapat suatu arus kontinu dari persediaan barang di dalam stok. Metode Economic Order Quantity $(E P Q)$ digunakan untuk mencari:

\section{Kuantitas optimal persediaan (Q)}

Penghitungan ini betujuan mendapatkan besarnya persediaan optimal sehingga meminimumkan biaya langsung penyimpanan persediaan dan meminumkan biaya pemesanan persediaan. Untuk menghitung kuantitas optimal yaitu menggunakan rumus:

$$
Q=\sqrt{\frac{2 D S}{H\left(1-\frac{d}{p}\right)}}
$$

Keterangan:

$$
\begin{array}{ll}
\mathrm{Q} & =\text { kuantitas optimal persediaan (kuintal) } \\
\mathrm{D} & =\text { jumlah kebutuhan bahan baku (kuintal) } \\
\mathrm{S} & =\text { biaya pemesanan (rupiah/pemesanan) } \\
\mathrm{H} & =\text { biaya penyimpanan (rupiah/kuintal/) } \\
\mathrm{d} & =\text { laju giling tebu (kuintal/jam) } \\
\mathrm{p} & =\text { laju produksi tebu (kuintal/jam) }
\end{array}
$$

2. Kuantitas optimal persediaan (Q)

Total waktu giling merupakan kesuluruhan waktu yang digunakan dalam satu kali siklus giling. Untuk menghitung total waktu giling adalah sebagai berikut:

$$
t=\frac{Q}{d}
$$

Keterangan:

$$
\begin{array}{ll}
\mathrm{Q} & =\text { kuantitas optimal persediaan (kuintal) } \\
\mathrm{d} & =\text { laju giling tebu (kuintal/jam) } \\
\mathrm{t} & =\text { total waktu giling (jam) }
\end{array}
$$

3. Kuantitas optimal persediaan (Q)

Waktu produksi adalah waktu dimana memproduksi bahan baku sekaligus penggunaan bahan baku untuk melakukan produksi produk. Untuk menghitung waktu produksi adalah sebagai berikut:

$$
t p=\frac{Q}{p}
$$

Keterangan:

tp = waktu produksi (jam)

$\mathrm{Q} \quad=$ kuantitas optimal persediaan (kuintal)

$\mathrm{p} \quad=$ laju produksi tebu (kuintal/jam)

4. Kuantitas optimal persediaan (Q)

Waktu penggunaan merupakan waktu yang digunakan untuk meproduksi produk tanpa memproduksi bahan baku atau pengadaan bahan baku. Untuk menghitung waktu penggunaan yaitu sebagai berikut:

$$
t p=t-t p
$$

Keterangan:

td = waktu penggunaan (jam)

$\mathrm{t} \quad=$ total waktu produksi (jam)

tp = waktu produksi (jam)

5. Kuantitas optimal persediaan (Q)

Maksimum inventory merupakan jumlah persediaan yang paling besar atau tertinggi yang boleh diadakan suatu perusahaan.untuk menghitung maksimum inventory dapat menggunakan formulasi:

$$
I=Q\left(1-\frac{d}{p}\right)
$$

Keterangan:

I = persediaan maksimum suatu perusahaan (kuintal)

$\mathrm{Q} \quad=$ kuantitas optimal persediaan (kuintal)

$\mathrm{d} \quad=$ laju giling tebu (kuintal/jam)

$\mathrm{p} \quad=$ laju produksi tebu (kuintal/jam)

6. Kuantitas optimal persediaan (Q)

Biaya total merupakan biaya yang dikeluarkan dalam pengadaan bahan baku yang bertujuan untuk membuktikan bahwa dengan melakukan pembelian bahan baku yang optimal yang dihitung menggunakan $E P Q$ akan dicapai biaya total persediaan bahan baku yang optimal.

$$
\text { biaya total }=\frac{D}{Q} s+\frac{Q}{2}\left(1-\frac{d}{p}\right)
$$

Keterangan:

$\mathrm{Q} \quad=$ kuantitas optimal persediaan (kuintal)

$\mathrm{D}=$ jumlah kebutuhan bahan baku (kuintal)

$\mathrm{S} \quad$ = biaya pemesanan (rupiah/pemesanan)

$\mathrm{H}$ = biaya penyimpanan (rupiah/kuintal/hari)

$\mathrm{d} \quad=$ laju giling tebu (kuintal/jam)

$\mathrm{p} \quad=$ laju produksi tebu (kuintal/jam)

\section{Hasil dan Pembahasan}

Bahan baku utama yang digunakan oleh PG Madukismo adalah tebu yang diperoleh dari kerja sama dengan petani yang berada di sekitar pabrik. Proses kerja sama ini biasanya didahului dengan proses perolehan lahan untuk melakukan kemitraan. Proses perolehan lahan digunakan untuk memperoleh lahan tanam perkebunan tebu dari petani dengan sistem kerja sama. Hal ini dikarenakan PG Madukismo tidak memiliki lahan sendiri sehingga PG Madukismo bekerja keras 
dalam melakukan kerjasama dengan petani guna memperoleh lahan untuk menanam tebu.

PG Madukismo dalam memenuhi kebutuhan tebunya dengan melakukan kemitraan terhadap petani. Terdapat tiga jenis pola kerjasama dalam pengadaan bahan baku di PG Madukismo dengan petani. Kerjasama ini meliputi Tebu Rakyat Mandiri, Tebu Rakyat Kerjasama Usaha, dan Tebu Rakyat Kemitraan.

Tebu Rakyat Mandiri (TRM) merupakan pola kerjasama yang dilakukan oleh PG Madukismo dengan petani yang mana petani lebih dominan dalam melakukan usaha taninya. Petani atau pemilik lahan melakukan sendiri kegiatan pencarian lahan, pengerjaan kebun, pembiayaan, dan pengangkutan, sedangkan PG Madukismo melakukan pinjaman modal biaya garap maupun saprodi apabila petani membutuhkan. Pihak PG Madukismo memberikan penyuluhan-penyuluhan tentang teknis budidaya yang baik dan benar kepada petani dengan tujuan agar kegiatan budidaya yang dilakukan tidak menyimpang dari standar operasional prosedur (SOP). Apabila petani tidak mempunyai biaya dalam melakukan usaha tani tebu, mereka dapat melakukan pengajuan dana kredit yang disediakan oleh PG Madukismo yang berasal dari dana CSR dan KKP-E (Kredit Ketahanan Pangan dan Energi). PG madukismo bertindak sebagai alfalis (penjamin) dan dana tersebut dapat dikembalikan oleh petani setelah giling dilaksanakan, yaitu dengan pemotongan hasil dari gula yang dihasilkan. Pembagian keuntungan dalam pola kerjasama Tebu Rakyat Mandiri sebesar 34\% milik PG Maduksimo dan $66 \%$ milik petani. Bagian petani tersebut terbagi menjadi $90 \%$ dalam bentuk uang dan $10 \%$ dalam bentuk natura yaitu gula pasir.

Tebu Rakyat Kemitraan (KMT) merupakan pola kerjasama antara PG Madukismo dengan pemilik lahan yang mana pengelolaan sepenuhnya dilakukan oleh PG Madukismo, terdiri dari Sinder Kebun Wilayah sebagai penanggung jawab yang dibantu oleh mandor, tenaga kerja harian, dan tenaga kerja borongan dalam melakukan kegiatan pengelolaannya. Untuk mendapatkan dana dalam penyewaan dan pengelolaan, PG Madukismo menggunakan dana CSR dan pengajuan dana kredit kepada BRI. Kredit yang diajukan adalah Kredit Ketahanan Pangan dan Energi (KKP-E) dari pemerintah dan PG Madukismo sebagai penjamin kredit tersebut. Apabila nantinya ada kerugian dalam proses penyediaan bahan baku tebu, pihak PG Madukismo yang akan mengganti rugi kepada pihak bank. Pada pola kerjasama ini petani memberikan lahannya kepada pihak PG Maduksimo untuk ditanami tebu dan petani mendapatkan dana Jaminan Pendapatan Minimum (JPM) yang disesuaikan dengan potensi lahan dan kesepakatan yang telah disepakati bersama. Apabila dalam proses budidaya tebu mengalami kerugian, petani tidak akan merasakan dampaknya karena sebelumnya mereka telah mendapatkan jaminan pendapatan minimal tersebut, sedangkan PG mengalami kerugian karena kehilangan bahan baku yang akan digunakan untuk proses produksi dan harus mengembalikan uang yang telah dipinjam pihak bank. Pada pola ini, apabila terjadi kelebihan produksi pada lahan sawah dimana hasil produksi tersebut melebihi 80 kuintal/hektar gula, maka 20\% sisanya diberikan kepada pemilik lahan. Pada lahan tegalan, jika terjadi kelebihan produksi melebihi
60 kuintal/hektar gula maka 20\% sisanya diberikan kepada pemilik lahan.

Rakyat Kerjasama Usaha (TR KSU) merupakan pola kerjasama khusus untuk lahan sawah berpengairan teknis dimana pola pengelolaan dan budidayanya dilakukan oleh kelompok tani yang mana pemilik lahan menunjuk salah satu dari anggota kelompok tani tersebut menjadi ketua atau pimpinan dan Sinder Kebun Wilayah (SKW) sebagai penanggung jawan yang dibantu oleh mandor dalam pembukaan lahan dan tenaga kerja. Dalam pengerjaannya, petani berperan dalam proses budidaya sedangkan PG Madukismo berperan sebagai penanggung jawab teknisnya. Dilihat dari segi biaya petani bersama PG Madukismo melakukan pembiayaan bersama, apabila kekurangan nantinya petani dapat mengajukan kredit melakui PG melalui dana CSR mapun pengajuan kepada bank BRI dan kredit yang diajukan adalah kredit ketahanan pangan dan energi (KKP-E) dari pemerintah dan PG sebagai penjaminnya. Pola kerjasama ini petani memberikan lahannya untuk dapat ditanami tebu dan petani mendapatkan jaminan pendapatan minimum (JPM) sesuai dengan potensi lahan dan kesepakatan yang telah disepakati bersama. Apabila dalam proses budidaya tebu mengalami kerugian, petani tidak akan merasakan dampaknya karena mereka sebelumnya telah mendapatkan jaminan pendapatan minimal tersebut, sedangkan PG mengalami kerugian yaitu kehilangan bahan baku untuk proses produksi dan harus mengembalikan uang yang telah dipinjam pihak bank. Selain mendapatkan jaminan pendapatan minimum, petani juga mendapatkan sisa hasil usaha (SHU) dan keuntungan $100 \%$ milik petani.

Selain melakukan pola kerja sama dengan petani, PG Madukismo melakukan pencarian tebu luar daerah binaan. Hal ini dilakukan karena PG Madukismo mengalami kekurangan bahan baku. Pencarian tebu luar daerah meliputi daerah Purbalingga, Banyumas, Banjarnegara, Sragen, Wonogiri, Klaten, Boyolali, Semarang, Jepara, Kudus, Pati, Blora, dan Salatiga. Pencarian tebu luar daerah berjumlah 1.621 .778 kuintal atau sebesar 46,2\% dari tebu yang digiling oleh PG Madukismo tahun 2018. Kondisi ini dikarenakan oleh semakin berkurangnya lahan perkebunan tebu di wilayah binaan PG Madukismo sendiri akibat dari alih fungsi lahan menjadi perumahan, penanaman komoditas pertanian lain yang lebih menguntungkan seperti semangka, melon, dan cabai di daerah pantai selatan, penggunaan lahan tebu untuk bandara yang berada di Kulon Progo, dan menurunnya harga gula yang menyebabkan petani enggan menanam tebu.

Kelebihan bahan baku tebu terjadi saat petani luar daerah binaan ingin menjual tebunya tanpa mempertimbangkan kondisi PG sehingga PG membeli tebu yang ada di luar binaan dengan cepat karena persaingan dengan pabrik gula lain dan untuk memenuhi target giling yang ada di PG Madukismo. Oleh karena itu, pihak PG membeli tebu tersebut tanpa mempertimbangkan kondisi pabrik yang ada. Selain dari tebu luar daerah PG Madukismo terjadi kelebihan bahan baku karena petani mandiri secara sepihak memutuskan jadwal penebangan tanpa pertimbangan kondisi PG karena berbagai alasan, sehingga pihak PG menerima tebu dari petani tersebut. Hal ini dikarenakan pihak PG harus tetap menjalin hubungan baik terhadap petani sehingga petani tebu tidak memutuskan kerja sama dengan pihak PG Madukismo. Jika hal ini terus 
terjadi maka akan menyebabkan ketidakpastian jumlah tebu setiap harinya yang berpengaruh terhadap julah giling yang ada di di PG Madukismo. Terkadang pabrik mengalami kelebihan bahan baku dan ada saatnya PG menagalami kelebihan bahan baku.

Untuk menghadapi hal tersebut, PG Madukismo tetap menerima semua tebu yang masuk walaupun banyak sisa pagi. Hal ini dimaksudakan agar pabrik tetap berjalan walaupun nantinya kualitas tebu menurun akibat berlebihan. Sementara PG menerima seluruh tebu yang masuk tersebut, pihak PG juga melakukan pengaturan tebu yang bekerja sama melalui kemitraan yaitu dengan menyetop tebu-tebu kemitraan untuk tidak dilakukan penebangan dan pengangkutan. Hal ini dilakukan karena pengendalian penebangan dapat dilakukan pada lahan-lahan yang melakukan kerjasama. Biasanya tebutebu kemitraan dilakukan penebangan dan pengangkutan di akhir musim giling. Hal ini dimaksudkan agar tebu yang bermitra di berlakukan sebagai cadangan untuk menghadapi permasalahan apabila nantinya kekurangan bahan baku.

Oleh karena itu, perlu adanya perbaikan sistem pengendalian bahan baku menggunakan Economic Production Quantity (EPQ) sehingga jumlah persediaan tebu merata hingga akhir musim giling. Hal ini di ini diharapkan natinya PG Madukismo dapat menggiling tebunya secara berkelanjutan karena jumlah tebu dapat terkontrol dengan baik.

\subsection{Economic Production Quantity (EPQ)}

Bahan baku merupakan unsur yang sangat penting dalam menunjang kelancaran produksi di PG Madukismo untuk mengolah tebu menjadi gula pasir. Jumlah bahan baku sangat menentukan keefektifan dan keefisienan PG Madukismo dalam kegiatan produksinya. Apabila jumlah bahan baku tebu yang ada optimal nantinya pabrik dapat menekan biaya seekonomis mungkin. Untuk mengetahui apakah pengendalian bahan baku tebu di PG Madukismo sudah efisien, maka dapat digunakan metode Economic Production Quantity (EPQ) saat keadaan ekonomis dengan penerimaan bertahap. Metode ini dirasa cukup tepat untuk mengendalikan bahan baku di pabrik gula karena bahan baku tebu yang dihasilkan berasal dari produksi sendiri dan proses produksi di PG dilakukan secara kontinue sehingga memungkinkan penerimaan bahan baku secara bertahap.

Data yang digunakan untuk menghitung jumlah optimal persediaan bahan baku tebu dengan menggunakan metode Economic Production Quantity (EPQ) meliputi data kuantitas giiling per hari (D), biaya persiapan per persediaan (S), biaya penyimpanan per kuintal per hari $(\mathrm{H})$, laju produksi tebu per hari (p), dan laju giling tebu (d).

\subsubsection{Kuantitas Giling per Hari (D)}

Kuantitas giling per hari PG Madukismo diperoleh jumlah total tebu pada 1 musim giling dibagi dengan total hari penggilingan. Berikut merupakan formulasi dari kuantitas giling perhari.

$$
D=\frac{\text { jumlah total tebu pada } 1 \text { musim giling }}{\text { total hari penggilingan }}
$$

$$
\begin{array}{r}
D=\frac{3.507 .892}{136} \\
D=25.793 \text { kuintal }
\end{array}
$$

Berdasarkan penghitungan kuantitas giling per hari pada PG Madukismo diperoleh rata-rata kuantitas giling harian PG Madukismo sebesar 25.793 kuintal. Kuantitas tersebut masih kurang dari kapasitas giling pabrik yang terpasang yaitu sebesar 35.000 kuintal. Oleh karena itu, perlu adanya pengendalian bahan baku agar pabrik dapat menggiling tebu dalam jumlah yang optimal.

\subsubsection{Biaya persiapan per persediaan $(S)$}

PG Madukismo dalam memenuhi kebutuhan bakunya yaitu dengan memproduksi sendiri sehingga biaya pemesanan menjadi biaya persiapan yaitu biaya yang dikeluarkan dalam rangka mengadakan bahan baku. Biaya tersebut meliputi biaya tersebut meliputi biaya analisa pendahuluan, alat tebang, kelancaran jalan, administrasi, dan tenaga kerja. Biaya analisa pendahuluan adalah biaya yang dikeluarkan untuk menentukan tingkat kemasakan tebu serta untuk mengetahui potensi rendemen yang akan diperoleh PG Madukismo. Biaya - biaya tersebut meliputi biaya konsumsi tenaga kerja dan biaya transportasi yang melakukan analisa pendahuluan. Biaya alat tebang merupakan biaya yang dikeluarkan dalam membeli peralatan tebang seperti bedog. Biaya kelancaran jalan merupakan biaya yang dikeluarkan dalam rangka perizinan penggunaan jalan umum yang digunakan sebagai jalan truk dalam mengangkut tebu. Biaya administrasi merupakan biaya yang dikeluarkan dalam pencatatanpencatatan dan pengeluaran surat-surat yang menyangkut kegiatan tebang dan angkut tebang seperti Surat Perintah Tebang (SPT), Surat Perintah Angkut (SPA), alat tulis mandor tebang, dan alat tulis kantor dan emplasment. Biaya tenaga kerja merupakan biaya operasional mandor, biaya persaksian kontrak mandor, biaya konsumsi mandor, biaya tarnspor santiaji mandor, biaya kontrak truk, biaya konsumsi rapat kontraktor truk, biaya sosialisasi tarif angkut dan lalu lintas, biaya doa bersama komunitas truk dan tebang angkut. Berikut merupakan biaya yang di keluarkan PG Madukismo dalam rangka menyediakan bahan baku.

Tabel 2.

Komponen Biaya Persediaan

\begin{tabular}{clr}
\hline No & \multicolumn{1}{c}{ Jenis Biaya } & Dikeluarkan (Rupiah) \\
\hline 1 & Biaya analisa pendahuluan & 1.665 .000 \\
3 & Biaya Alat tebang, dan tikar & 70.362 .500 \\
4 & Biaya kelancaran jalan & 169.800 .000 \\
5 & Biaya administrasi & 63.367 .000 \\
6 & Biaya tenaga kerja & 856.342 .000 \\
7 & Total biaya per tahun & 1.161 .536 .500 \\
8 & Total biaya per persediaan & 8.478 .369 \\
\hline
\end{tabular}

Tabel 2. menunjukkan biaya yang dikeluarkan dalam satu periode giling tahun 2018 sebanyak Rp 1.161.536.500 yang dilakukan sebanyak 137 kali pengiriman sehingga biaya yang dikeluarkan dalam sekali pengiriman sebesar Rp 8.478.369. 


\subsubsection{Biaya Penyimpanan}

Biaya penyimpanan pada PG Madukismo merupakan biaya yang dikeluarkan pada saat tebu memasuki pabrik hingga menunggu jatah giling. Penyimpanan bahan baku di PG ini bersifat sementara untuk menunggu proses giling karena pada dasarnya tebu hanya bisa disimpan selama 36 jam. Biaya - biaya yang dikeluarkan dalam penyimpanan tebu yaitu sebagai berikut:

Tabel 3.

Komponen biaya penyimpanan

\begin{tabular}{lc}
\hline Jenis Biaya & Dikeluarkan (Rupiah) \\
\hline Biaya bongkar & 277.134 .275 \\
Biaya listrik & 25.486 .613 \\
Biaya perawatan derek & 23.065 .000 \\
Biaya solar & 195.976 .000 \\
Biaya perawatan loko, riilban, dan & 351.000 .000 \\
empalsment & \\
Biaya tenaga kerja & 659.936 .040 \\
Total biaya penyimpanan & 1.532 .597 .928 \\
Total penyimpanan per kuintal & 436,89 \\
\hline
\end{tabular}

Terdapat 6 biaya yang dikeluarkan dalam penyimpanan bahan baku. Biaya tersebut meliputi biaya bongkar, perawatan derek, listrik, solar, perwatan loko, dan tenaga kerja. Biaya bongkar merupakan biaya yang dikeluarkan dalam rangka pembongkaran tebu yang datang ke PG. Biaya pembongkaran ini meliputi biaya tenaga kerja dalam pemriksaan kuantitas dan kualitas tebu yaitu Bersih, Manis, dan Segar. Biaya listrik yaitu biaya yang dikeluarkan dalam rangka pembayaran listrik dalam crane untuk mengangkat tebu dari truk ke lori dan lori ke meja tebu. Biaya perwatan derek yaitu biaya yang dikeluarkan untuk melakukan pemeliharaan-pemeliharaan crane. Biaya solar merupakan biaya bahan bakar untuk loko dalam mengangkut tebu. Biaya perawatan loko, riilban, dan emplasment yaitu biaya yang digunakan untuk pemeleiharaan loko pengangkut tebu, jembatan timbang, rel kereta, dan alatalat kebersihan untuk pembersiahan rel kereta.

Pada tabel tentang penyimpanan bahan baku tebu, biaya penyimpanan yang dikeluarkan dalam satu periode giling tahun 2018 sebesar $\mathrm{Rp}$ 1.532.597.928 untuk menyimpanan sebanyak 3.507.892 kuintal, sehingga biaya penyimpanan per kuintal sebesar Rp 436,89.

\subsubsection{Laju Produksi Tebu per Jam (p)}

Laju produksi tebu per hari merupakan kecepatan tebu yang ditebang per hari. Laju peroduksi tebu dihasilkan dari jumlah tebu yang ditebang dibagi dengan jumlah hari tebang dan dibagi dengan jam kerja tebang. Jam kerja penebang yaitu 10 jam yang dimulai dari pukul 05.30-17.30 WIB. Formulasi laju produksi tebu harian yaitu sebagai berikut.

$$
\begin{aligned}
& p=\frac{\frac{3.507 .892}{137}}{10} \\
& p=2.560 \mathrm{kuintal} / \mathrm{jam}
\end{aligned}
$$

Laju produksi tebu yang dihasilkan perjamnya yaitu 2.560 artinya setiap 1 jam juru tebang yang berkerja menebang setiap harinya dapat menghasilkan 2.560 kuintal tebu.

\subsubsection{Laju Giling Tebu per Jam (kuintal)}

Laju giling tebu per jam merupakan kecepatan tebu yang mengalami penggilingan perjamnya . Penggilingan tebu dilakukan selama 24 jam atau seharian penuh. Untuk menghitung laju giling tebu per jam yaitu dengan formula jumlah total tebu dibagi dengan jumlah hari giling dan dibagi jam kerja giling yaitu 24 jam. Laju giling tebu yang dihasilkan perjamnya yaitu 1074 kuintal artinya setiap 1 jam tebu yang dapat digiling yaitu sebesar 1074kuintal.

$$
\begin{aligned}
& d=\frac{\frac{3.507 .892}{136}}{24} \\
& d=1074 \mathrm{kuintal} / \mathrm{jam}
\end{aligned}
$$

Dari penghitungan komponen-komponen data diatas, maka dapat diperoleh tabel data untuk menghitung $E P Q$ yaitu sebagai berikut.

Tabel 4.

Data untuk Menghitung EPQ Dalam di PG Madukiskmo Tahun 2018

\begin{tabular}{ccccc}
\hline $\begin{array}{c}\mathrm{D} \\
\text { (kuintal) }\end{array}$ & $\begin{array}{c}\mathrm{S} \\
(\mathrm{Rp})\end{array}$ & $\begin{array}{c}\mathrm{H} \\
(\mathrm{Rp})\end{array}$ & $\begin{array}{c}\mathrm{P} \\
(\text { kuintal/jam) }\end{array}$ & $\begin{array}{c}\mathrm{D} \\
\text { (kuintal/jam) }\end{array}$ \\
\hline 25.793 & 8.478 .369 & 436,89 & 2.560 & 1.074 \\
\hline
\end{tabular}

Berdasarkan tabel yang berisi data komponen penghitungan $E P Q$ tersut dalam keadaan ekonomis untuk mengendalian bahan baku di PG Madukismo menggunakan persamaan $E P Q$, diperoleh hasil sebagai berikut:

1. Kuantitas Optimal Persediaan (Q)

Kuantitas optimal persediaan merupakan jumlah persediaan yang paling menguntungkan apabila dapat menyediakan bahan baku tebu dengan tepat. Untuk menghitung kuantitas optimal dapat diperoleh dengan persamaan:

$$
\begin{gathered}
E P Q=\sqrt{\frac{2 D S}{H\left(1-\frac{d}{p}\right)}} \\
E P Q=\sqrt{\frac{2 \times 25.793 \times 8.478 .369}{436,89\left(1-\frac{1074}{2560}\right)}} \\
Q *=41.529 \text { kuintal }
\end{gathered}
$$

Menurut penghitungan, kuantitas optimal persediaan per penyediaan yaitu sebesar 41.529 kuintal sedangkan kuantitas giling PG Madukismo tahun 2018 rata-rata sebesar 25.5793 kuintal. Jumlah persediaan bahan baku yang ada di PG Madukismo masih kurang yaitu dibawah kapasaitas giling 
pabrik sebesar 35.000 kuintal sedangkan persediaan menurut metode EPQ diatas kapasitas giling pabrik yaitu 35.000 kuintal dan 6.529 kuintal sisanya untuk persediaan atau jagajaga hari giling berikutnya. Sehingga PG Madukismo membutuhkan pengendalian bahan baku agar persediaan bahan baku yang ada optimal.

\section{Total Waktu Giling (t)}

Total waktu giling merupakan keseluruhan waktu yang digunakan untuk menggiling tebu. Tebu yang digiling secara keseluruhan, baik dalam kondisi menggiling tebu dengan menebang tebu dan keadaan menggiling tebu tanpa dilakukan penebangan tebu karena persediaan masih ada. Untuk menghitung total giling yaitu dengan membagi antara kuantitas persediaan tebu yang optimal (Q) dengan laju giling tebu (d).

$$
\begin{gathered}
t=\frac{Q}{d} \\
t=\frac{41.529}{1074} \\
t=38,6 \text { jam }
\end{gathered}
$$

Waktu total giling yang dihasilkan yaitu sebesar 38,6 jam. Menurut standar PG Madukismo, tebu hanya boleh didiamkan selama 36 jam atau 1,5 hari setelah penebangan dilakukan. Hal ini bertujuan agar standar kualitas tebu masih dalam kondisi Bersih, Manis, dan Segar (BSM). Dengan pertimbangan ini watu total giling menggunakan metode $E P Q$ masih efektif diterapkan di PG Madukismo karena tebu masih dianggap masih memenuhi standar walaupun selisih 2,6 jam.

\section{Waktu Produksi (tp)}

Waktu produksi merupakan waktu yang digunakan untuk menggiling tebu sekaligus dilakukan penebangan tebu. Berikut merupakan penghitungan waktu produksi.

$$
\begin{gathered}
t p=\frac{Q}{p} \\
t p=\frac{41.529}{2.560} \\
t p=16,2
\end{gathered}
$$

Waktu produksi yang dihasilkan yaitu 16,2 jam. Menurut standar PG Madukismo waktu produksi yaitu waktu yang dilakukan untuk melakukan penebangan dan penggilingan. Waktu produksi di PG Madukismo yaitu 10 jam yang dimulai pukul 05.30-17.30. Apabila nantinya PG Madukismo akan menerapkan EPQ sebagai metode dalam pengendalian bahan baku artinya harus menambah jam kerja penebang selama 6,2 jam atau dengan menambah pekerja tebang.

\section{Waktu Giling Tanpa Produksi (td)}

Waktu yang digunakan untuk melakukan penggilingan tebu tanpa melakukan penebangan tebu. Untuk memperoleh waktu giling tanpa produksi dapat diperoleh dari selisih dari total waktu giling dengan waktu produksi. Berikut merupakan formula dari waktu giling tanpa produksi.

$$
\begin{aligned}
& t d=t-t p \\
& t d=38,6-16,2 \\
& t d=22,4
\end{aligned}
$$

Hasil dari waktu giling tanpa produksi tebu yaitu 22,4 jam. Artinya tebu hanya dilakukan penggilingan saja tanpa adanya penebangan tebu karena tebu masih tersedia

\section{Maksimum Inventory}

Maksimum inventory merupakan batas jumlah persediaan yang paling maksimal yang sebaiknya dilakukan oleh perusahaan. Persediaan maksimum bertujuan agar jumlah persediaan yang ada di gudang tidak berlebihan yang tidak menimbulkan suatu kerugian. Begitupun juga PG Madukismo dalam melakukan persediaannya harus ada batasan maksimumnya karena bahan baku tebu di PG Madukismo mudah rusak sehingga persediaan harus dikontrol dengan baik agar tebu tidak mengalami penurunan kualitas standar Bersih, Manis, dan Segar (BSM) karena adanya kelabihan bahan baku. Berikut merupakan penghitungan batas maksimum persediaan tebu di PG.

$$
\begin{gathered}
\text { persediaan Maksimum }=Q\left(1-\frac{d}{p}\right) \\
\text { persediaan maksimum }=41.529\left(1-\frac{1074}{2560}\right) \\
\text { persediaan maksimum }=24.106 \text { kuintal }
\end{gathered}
$$

Persediaan maksimum yang boleh dilakukan sebesar 24.106 kuintal. Jika dilihat persediaannya PG Madukismo pernah mengalami sisa pagi atau tebu persediaan yang digunaan untuk persediaan sebanyak 51.385 kuintal. Oleh karena itu PG Madukismo membutuhkan pengendalian bahan baku agar tidak mengalami kelebihan bahan baku yang dapat menurunkan kualitas tebu.

\section{Total Cost}

Total cost merupakan biaya total yang dikeluarkan dalam rangka penyediaan bahan baku tebu. Berikut merupakan penghitungan biaya total menurut metode $E P Q$ sebagi berikut.

$$
\begin{aligned}
& \text { Total Cost }=\frac{D}{Q} S+\frac{Q}{2}\left(1-\frac{d}{p}\right) H \\
& \text { Total Cost }=\frac{25.793}{41.529} \times 8.478 .369+\frac{41.529}{2}\left(1-\frac{1074}{2560}\right) 436,89
\end{aligned}
$$

Total Cost $=10.545 .104$ per persediaan 
Total biaya yang dikeluarkan PG Madukismo dalam memenuhi kebutuhan bahan baku tahun 2018 sebesar Rp 2.694.134.428. Menurut metode EPQ saat keadaan ekonomis dan persediaan bertahap sebesar $\mathrm{Rp} 10.545 .104$ per persediaan. Persediaan dilakukan 85 kali dalam satu periode giling segingga total biaya yang dikeluarkan sebesar $\mathrm{Rp}$ 896.333.840 artinya ada selisih pengeluaran menurut kebijakan perusahaan dan metode $E P Q$ yaitu sebesar $\mathrm{Rp}$ 1.797.800.588 atau sebesar 66,7\% dari biaya total yang dikeluarkan perusahaan. Berikut merupakan model persediaan bahan baku tebu di PG Madukismo dengan metode Economic Production Quantity (EPQ).

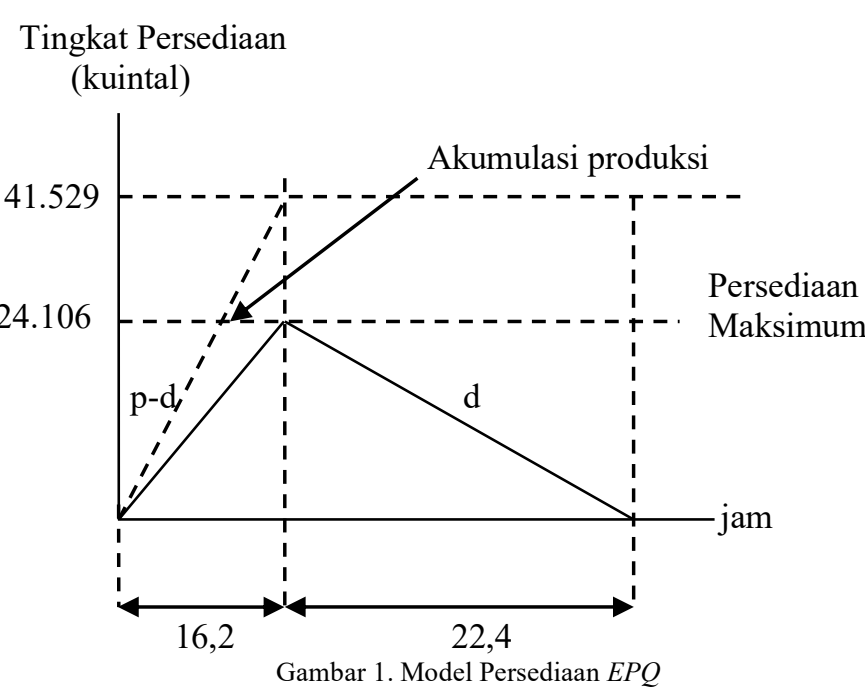

Berdasarkan gambar 1 memperlihatkan penerapan metode $E P Q$ di PG Madukismo. Grafik tersebut menunjukkan kuantitas penyediaan bahan baku optimal, persediaan maksimum dan siklus giling. Kuantitas penyediaan bahan baku yang optimal atau total persediaan dalam akumulasi produksi sebesar 41.529. Satu kali siklus giling dilakukan selama 38,6 jam atau 1,608 hari dan berlanjut sampai hari ke 136 dengan frekuensi 84 kali penggilingan. Produksi tebu dilakukan selama 16,2 jam dengan laju produksi sebesar 2560 kuintal/jam, selain melakukan produksi tebu dilakukan pula penggilingan tebu dengan laju produksi $1.074 \mathrm{kuintal} / \mathrm{jam}$. Kondisi ini dilambangkan dengan p-d dengan slope miring. Hal Ini dikarenakan pesanan tidak diterima semua secara sekaligus melainkan secara bertahap. Setelah tebu mencapai produksi yang optimal dan persediaan tebu dalam keadaan maksimum, kegiatan produksi tebu dihentikan. Akan tetapi kegiatan giling tetap dilanjutkan yaitu pada kondisi p. Pada kegiatan ini dilakukan penggilingan tebu yang masih tersisa dari persediaan maksimum sebesar 24.106 kuintal yang dilakukan selama 22,4 jam. Kemudian dilanjutkan untuk siklus giling berikutnya dengan kondisi yang sama. Dengan penerapan metode EPQ ini nantinya perusahaan dapat menghemat biaya dalam pengendalian bahan baku sehingga tidak terjadi kerugian baik dari segi biaya maupun kualitas tebu.

\section{Kesimpulan}

Berdasarkan penelitian mengenai analisis pengendalian bahan baku menggunakan metode Economic Production Quantity (EPQ) di PG Madukismo, Bantul, Yogyakarta, dapat diambil kesimpulan bahwa jumlah pengadaan bahan baku tebu yang optimal yaitu sebesar 41.529 kuintal dengan pengadaan bahan baku sebanyak 85 kali. Biaya total yang dikeluarkan PG Madukismo dalam pengadaan bahan baku menggunakan metode Economic Production Quantity (EPQ) sebesar Rp 896.333.840 dengan menurunkan biaya total pengadan bahan baku perusahaan sebesar $66,7 \%$.

Penelitian ini dilakukan dengan kondisi pengadan bahan baku yang normal artinya tidak mempertimbangkan bahan haku apakah kekurangan maupun berlebihan. Oleh karena itu, ntuk peneliti selanjutnya sebaiknya meneliti lebih mendalam ıengenai pengendalian bahan baku tebu dengan mempertimbangkan kondisi perusahan baik kelebihan maupun kekurangan persediaan.

\section{Referensi}

\section{Maksimum}

[1] Akindipe, O.S. The Role of Raw Material Management in Production Operations. Pnternational Journal of Managing Value and Supply Chains (IJMVSC). 5(3), 37-44. 2014.

[2] Andari, B. The Importance of Raw Materials Inventory Supervision for Production Process. JARES. 1(1), 53-60. 2016.

[3] Soekarwati. Pengantar Agroindustri. Jakarta: PT Raja Grafindo Persada. 2001.

[4] Pembengo W., Handoko., dan Suwarto. Efisiensi Penggunaan Cahaya Matahari Oleh Tebu Pada Berbagai Tingkat Pemmupukan Nitrogen dan Fosfor. J. Agr. Indonesia 40 (3):211-217. 2012.

[5] Yolanda, Y. Analisis Pengendalian Persediaan Bahan Baku di Pabrik Gula Gondang Baru Kabupaten Klaten. Surakarta: Universitas Sebelas Maret. 2012.

[6] Nana Syaodih Sukmadinata. Metode Penelitian Pendidikan. Bandung: PT. Remaja Rosdakarya. 2011.

[7] Stake, R. The art of case research. Thousand Oaks, CA: Sage Publications. doi: 10.2307/329758. 1995.

[8] Arikunto, Suharsimi, Prosedur Penelitian : Suatu Pendekatan Praktik, Edisi Revisi VI, Jakarta : PT Rineka Cipta, 2006.

[9] Herjanto, Eddy. Manajemen Operasi. Jakarta : Grasindo.2007. 